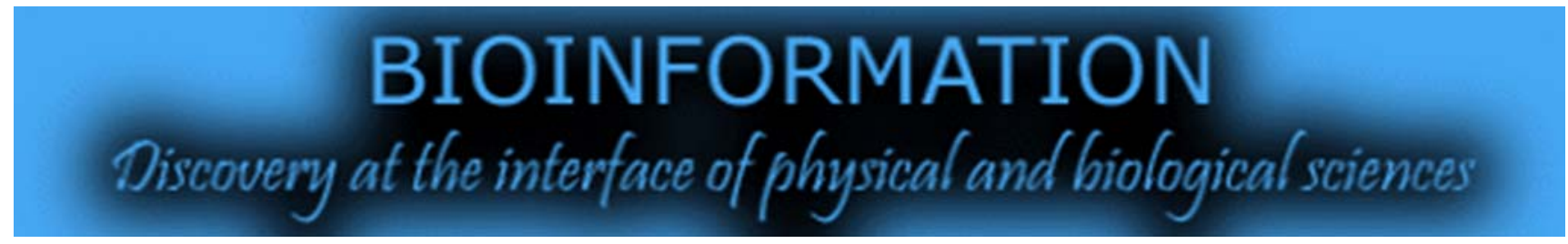

open access

www.bioinformation.net

Hypothesis

Volume 8(1)

\title{
Analysis of human collagen sequences
}

\author{
Manisha Nassa, Pracheta Anand, Aditi Jain, Aastha Chhabra, Astha Jaiswal, Umang Malhotra, \\ Vibha Rani*
}

Department of Biotechnology, Jaypee Institute of Information Technology, A-10, Sector-62, NOIDA, 201307, Uttar Pradesh, India; Vibha Rani - Email: vibha.rani@jiit.ac.in; phone: + (91)-120-2594210; *Corresponding author

Received December 07, 2011; Accepted December 16, 2011; Published January 06, 2012

\begin{abstract}
The extracellular matrix is fast emerging as important component mediating cell-cell interactions, along with its established role as a scaffold for cell support. Collagen, being the principal component of extracellular matrix, has been implicated in a number of pathological conditions. However, collagens are complex protein structures belonging to a large family consisting of 28 members in humans; hence, there exists a lack of in depth information about their structural features. Annotating and appreciating the functions of these proteins is possible with the help of the numerous biocomputational tools that are currently available. This study reports a comparative analysis and characterization of the alpha- 1 chain of human collagen sequences. Physico-chemical, secondary structural, functional and phylogenetic classification was carried out, based on which, collagens 12, 14 and 20, which belong to the FACIT collagen family, have been identified as potential players in diseased conditions, owing to certain atypical properties such as very high aliphatic index, low percentage of glycine and proline residues and their proximity in evolutionary history. These collagen molecules might be important candidates to be investigated further for their role in skeletal disorders.
\end{abstract}

Keywords: Biocomputational tools, Collagen, Comparative characterization, Extracellular matrix

\section{Background:}

The extracellular matrix (ECM) is an intricate network of macromolecules surrounding a substantial volume of cells. It comprises of collagens, proteoglycans, glycoproteins and proteases [1]. These components are arranged in a highly organized manner and play a significant role not only as a scaffold to the cell but also in multiple processes such as cell migration, cell-cell interaction and cell proliferation [2]. Collagens are the most abundant component of ECM. They form a triple helical structure with three distinct polypeptide chains, commonly known as the alpha chains. Also, this triple helix is found to possess a peculiar sequence 'Gly-Xaa-Yaa' [3]. The presence of glycine as every third residue accounts for the stability of the helical structure owing to its property of being the smallest amino acid. Xaa and Yaa can be any amino acid but are mostly occupied by the proline residue. Thus, collagen is known to be a glycine and proline rich entity. Collagen proteins are synthesized as inactive precursor forms known as procollagens. The cleavage of pro-peptides present at the $\mathrm{N}$ and $\mathrm{C}$

ISSN 0973-2063 (online) 0973-8894 (print)

Bioinformation 8(1): 026-033 (2012) terminal by peptidases forms the mature active collagen molecules.

The collagen family is a large and a complex family comprising of 28 genetically distinct members found in humans [4]. This diverse family includes fiber forming collagens, amorphous collagens, transmembrane collagens and a specialized type of collagen that forms unique structures [5]. The imperative role of collagen can be ascertained through the wide spectrum of pathological disorders that are associated with it. Mutations in the genes encoding for collagen proteins can lead to a variety of diseases such as Osteogenesis Imperfecta, Ehlers-Danlos syndrome, Spondyloepiphyseal dysplasia, Multiple epiphyseal dysplasia [6]. Furthermore, variations in the collagen content or a significant remodeling of the collagen network can lead to several dysfunctions like parenchymal disease, hypertensive heart disease, renal fibrosis, tumor and fibrotic diseases [7]. Computational biology is an emerging field that essentially helps to unveil the hidden information of a protein structure, 
both at the genomics and proteomics level. It integrates biology with computational algorithms for better understanding of complex molecules. Such analysis can be enhanced through a combinatorial dry to wet lab approach wherein the propositions made through the biocomputational findings can help in providing a direction for further research during wet lab studies. Thus, it facilitates to appreciate and understand the structural and functional roles of protein molecules, which are the heart of human disorders. A similar approach has been adopted to characterize the family of matrix metalloproteinases (MMP), where in silico characterization was followed by experimental confirmation and MMP-7 was subsequently proved to be a potential target in cardiac hypertrophy [8, 9]. Collagen and its derivatives, such as gelatin, act as substrates of MMPs and are involved in development of many pathological conditions. An extensive analysis of collagen family is hence essential to comprehend the process of matrix remodeling in diseases.

Our study reports a comparative characterization of alpha-1 sequences of human collagen using biocomputational tools. Of the three alpha chains present in collagen, alpha-1 was observed in all 28 human collagens; thus alpha- 1 was used for further analysis of the collagen proteins. The physico-chemical, secondary structural, functional and phylogenetic analysis of alpha-1 sequences of human collagen was executed. This research aims to provide an insight to various protein attributes of collagen proteins and characterize this large family. It also intends to propose potential members implicated in disease conditions based on relative examination of the collagen family or the presence of any atypical characteristics in the collagen molecules. This would aid biologists in carrying out further investigations on these complex molecules, for which, the basic structure analysis is of prime importance.

\section{Methodology: \\ Retrieval of human collagen alpha-1 protein sequences}

The complete alpha- 1 protein sequences of all 28 members of human collagen family reported till date were derived from UniProtKB/ SWISS-PROT, a curated protein database (http://expasy.org/sprot/) in FASTA format with the help of the accession number provided for each collagen sequence (http://www.uniprot.org/) [10]. Complete information about the origin, attributes, annotation, ontologies, binary interactions and sequence of proteins was found in this knowledgebase.

\section{Physico-chemical characterization of collagen family}

Various features including number of amino acids, molecular weight, theoretical isoelectric point (pI), amino acid composition (\%), number of positively (Arg + Lys) and negatively charged (Asp + Glu) residues, extinction co-efficient, instability index, aliphatic index and Grand Average of Hydropathicity (GRAVY) were computed using ExPASy's ProtParam tool using the protein sequence in FASTA format as the input data type (http://expasy.org/tools/protparam.html). Other physico-chemical features including number of codons, bulkiness, polarity, refractivity, recognition factors, hydrophobicity, transmembrane tendency, percent buried residues, percent accessible residues, average area buried, average flexibility and relative mutability were calculated for primary structure characterization by ExPASy's ProtScale tool using the retrieved protein sequence as the input data type (http://expasy.org/tools/protscale.html). A suitable amino acid scale was chosen for computation of each parameter in this sliding windows based tool that gives each amino acid a numerical value known as the amino acid scale.

\section{Secondary structural characterization of collagen family}

The secondary structural features of proteins comprising of alpha helix, $3_{10}$ helix, Pi helix, beta bridge, extended strand, beta turn, bend region, random coil, ambiguous states and other states were predicted using Self-Optimized Prediction Method with Alignment (SOPMA) tool that takes into account the information derived from alignment of protein sequences belonging to the same family (http://npsa-pbil.ibcp.fr/cgibin/npsa_automat.pl?page=npsa_sopma.html) [11]. The protein sequence in FASTA format was used as the input data type and the number of conformational states was adjusted to four in order to predict Helix, Sheet, Coil and Turn. The other parameters were set as default.

\section{Functional characterization of collagen family}

The Motif scan tool was used to scan and identify all the known motifs, their nature and location in the selected alpha-1 protein sequences of the collagen family based on a profile and pattern search (http://myhits.isb-sib.ch/cgi-bin/motif_scan) [12, 13]. The protein sequence in FASTA format was used as the input data type and scanned against 'PROSITE Patterns', a selected protein profile database out of the eight available.

\section{Phylogenetic classification of collagen family}

The human alpha-1 collagen protein sequences were aligned using multiple sequence alignment tool ClustalW2 using the protein sequences in FASTA format as the input data type (http://www.ebi.ac.uk/Tools/msa/clustalw2/) [14]. The best alignment for a set of input sequences was computed and all the identities, similarities and differences were highlighted. The evolutionary relationships were established by constructing phylograms through retrieval of the alignments using Neighbor Joining (NJ) method.

\section{Discussion:}

Functional role of alpha-1 chain of each human collagen was analyzed (Table 1, see Supplementary material). MultAlin tool was used to carry out protein sequence alignment wherein a decreased sequence similarity was witnessed with increasing number of input sequences [15]. It was inferred that the alpha-1 chain showed identities, similarities and differences at various positions along the protein sequence in all 28 members. The computation of amino acid composition of each human alpha-1 collagen sequence using ExPASY's ProtParam tool indicated very high percentages of glycine and proline as compared to other amino acids (Table 2, see Supplementary material). Glycine content in all collagens was more than $12 \%$, except Collagen 12, 14 and 20 with a value of 9.2, 10.9 and $11.5 \%$ respectively. High percentage of glycine accounts for the stability of collagen triple helical structure, since incorporation of large amino acids can cause steric hindrance [16]. Furthermore, proline content was more than $10 \%$ in most collagens except Collagen 6, 12, 14 and 20 with values 8.7, 8.6, 8.7 and $10 \%$, respectively. Proline residues are equally essential to point outward and stabilize the helix and also to act as structural disruptor of the secondary structural elements [17]. Thus, this not only helps collagen to act as a structural molecule 
but also aids in processes like cell-cell adhesion, migration. Other essential physico-chemical parameters were also calculated using ExPASy's ProtParam and ProtScale tools (Table $3 a$ and $\mathbf{3 b}$ see Supplementary material). The pI values for 15 collagens were found to lie in the acidic range, while for the remaining half, alkaline range was observed. Also, analysis of instability index classified most collagens as stable (instability index <40) while Collagen 15, 17, 18, 20 and 26 were declared as unstable collagens. Additionally, Collagen 20 was regarded most thermostable, with highest aliphatic index (79.61), describing the relative volume of protein occupied by aliphatic side chains, closely followed by Collagen 14 (77.67) and 12 (75.45). Furthermore, the GRAVY values, signifying interaction of collagens with water, were observed within a broad range of -0.261 to -0.919 , while the hydrophobicity was found to range between -0.3335 of Collagen20 (most hydrophilic) to 0.3335 of Collagen18 (most hydrophobic).

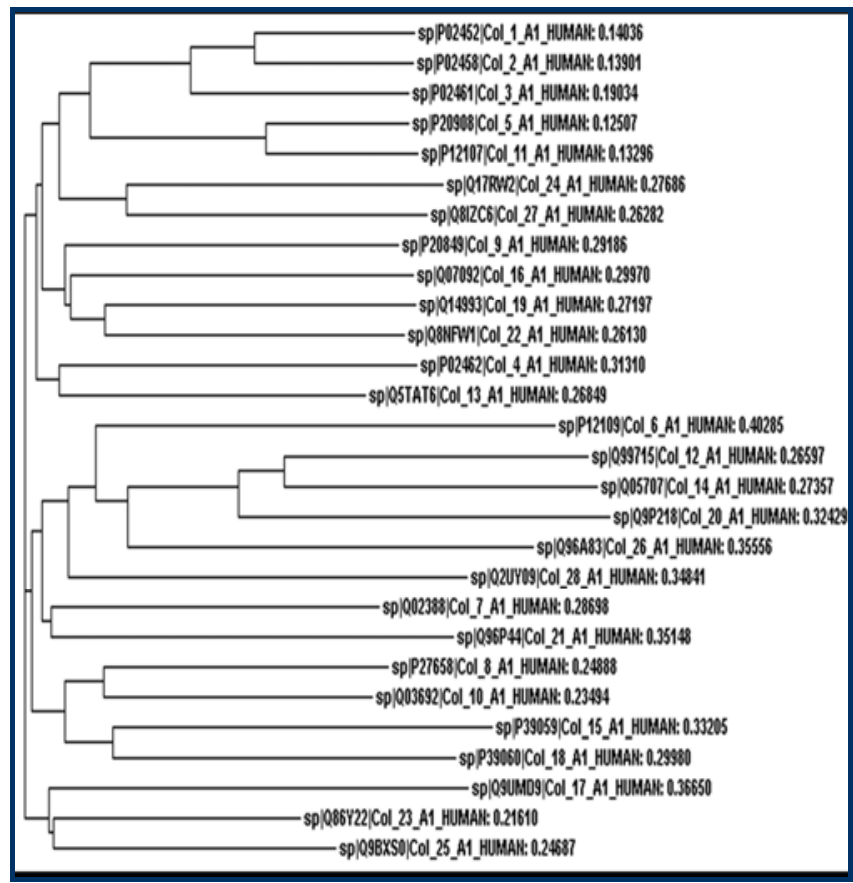

Figure 1: Phylogram of human alpha-1 collagens constructed using Neighbor Joining (NJ) method. Subject sequences were aligned using ClustalW2 multiple alignment tool and phylogenetic trees were constructed thereafter. Clusters with similar relations were identified such as Collagen 12 and 14, with Collagen 20 as their nearest neighbor.

SOPMA analysis of secondary structural features of human collagen protein sequences showed a pre-dominance of random coils while least percentage of $\beta$-turns were found. a-helices were found to exceed extended strands in 13 collagens (Collagen 6, 9, 13, 15, 17, 18, 19, 21, 22, 23, 25, 26 and 28) (Table 4 see Supplementary material). A high percentage of random coils facilitating self-assembly of the monomer units into welldefined structures can also be linked to high glycine and proline content that are vital to provide the desired flexibility and ability to bond with adjacent units in collagen monomers. This information on packaging of secondary structural elements may assist to derive potential tertiary protein structures and also promote advancements in protein engineering. Motifs of protein can provide significant knowledge about the protein's mechanism of action and nature. Signature motifs were obtained within protein sequences using Motif Scan tool (Table 5, see supplementary material). Collagens 1, 2 and 3 were found to possess the VWFC domain signature, known to participate in oligomerization, hence forming an imperative part of the complex forming proteins $[18,19]$. The presence of this domain can be correlated to the known characteristic of collagen molecules passing through a complex assembly process to form a triple helical structure. Additionally, Collagens 7 and 28 were observed to have pancreatic trypsin inhibitor (Kunitz) family signature. The 28 human alpha-1 collagen protein sequences were aligned based on sequence homology and phylogram was constructed with distance-based NJ method to establish evolutionary relations in the complex collagen family (Figure 1). Various clusters with close relationships were identified including Collagen 1 and 2, 12 and 14, 23 and 25 relating closely to Collagen 3, 20 and 17 respectively. These molecules may be analyzed together for possible similar properties owing to their close evolutionary history. Also, Collagen 4, reported majorly in diseases shows similarity to Collagen 13 , which may also potentially play a role in pathological conditions. Collagen 9, 12, 14 and 20 are included in the FACIT (Fibril Associated Collagens with Interrupted Triple helices) group of collagen family, where alpha-1 chain of Collagen 9 is recognized for its role in skeletal and rheumatoid disorders, especially in multiple epiphyseal dysplasias [20]. Owing to their structural similarities, atypical features and proximity in evolutionary history, the other members of this family also present a prime candidature for investigation of their role in skeletal disorders.

\section{Conclusion:}

With the availability of a wide variety of computational tools, an in-depth study of the information hidden behind a protein structure is possible. Comparative studies of the members belonging to a protein family and their physico-chemical, secondary structural, functional and phylogenetic classification can help give extensive information of protein's structure, function and its relationship with other members of the family. Characterization of the alpha- 1 chain of the vast collagen protein family in humans yielded new insights. Based on this comparative characterization, we hypothesize, Collagen 12, 14 and 20 as a potential protein cluster showing similarity in many properties along with an atypical behavior. These three proteins possess, low glycine and proline, very high aliphatic index and a close evolutionary relation. Since these collagens form a part of the FACIT collagen family, of which collagen 9 is established for its role in skeletal disorders, these collagen molecules might be possible disease candidates. These findings can help biologists working with ECM proteins concentrate their research on collagen proteins proposed as putative players in diseased conditions. Moreover, this study is a model for researchers to fine-tune their specific systems and comprehend their outcomes better.

\section{Acknowledgement:}

This work was supported by the research grant awarded to Dr. Vibha Rani by the Department of Science and Technology, Government of India (SR/FT/LS-006/2009: Sept 4, 2009). We acknowledges Jaypee Institute of Information Technology, Deemed to be University, for providing the required support. 
References:

[1] Jarvelainen H et al. PharmacollagenRev. 2009 61:198 [PMID: 19549927]

[2] Bowers SLK et al. J Mol Cell Cardiol. 2010 48: 474 [PMID: 19729019]

[3] Kadler KE et al. Biochem J. 1996 316: 1 [PMID: 8645190]

[4] Cen L et al. Pediat Res. 2008 63: 492 [PMID: 1842729]

[5] Tanzer ML. J Orthop Sci. 2006 11: 326 [PMID: 16721539]

[6] Bateman JF et al. Nat Rev Genetics. 2009 10: 173 [PMID: 19204719]

[7] Gonzalez A et al. Med Clin North Am. 2004 88: 83 [PMID: 14871052]

[8] Jaiswal A et al. Bioinformation. 2011 6: 23 [PMID: 21464841]

[9] Chhabra A et al. J Comput Intell Bioinformatics. 2011 4: 1

[10] Bairoch A \& Apweiler R. Nucleic Acids Res. 1997 25: 31[PMID: 9016499]

[11] Geourjon C \& Deleage G. Comput Appl Biosci. 1995 11: 681 [PMID: 8808585]
[12] Pagni M et al. Nucleic Acids Res. 2007 35: W433- [PMID: 17545200]

[13] Sigrist CJA et al. Nucleic Acids Res. 2010 38: D161 [PMID: 19858104]

[14] Larkin MA et al. Bioinformatics. 2007 23: 2947 [PMID: 17846036]

[15] Corpet F. Nucleic Acids Res. 1988 16: 100881 [PMID: 2849754]

[16] Van der Rest M \& Garrone R. FASEB J. 1991 5: 2814 [PMID: 1916105]

[17] Ramchandran GN et al. Biochemica et Biophysica Acta. 1973 332: 166 [PMID: 4744330]

[18] Hunt LT \& Barker WC. Biochem Biophys Res Commun. 1987 144: 876 [PMID: 3495268]

[19] Voorberg J et al. J Cell Biol. 1991 113: 195 [PMID: 2007623]

[20] Czarny-Ratajczak M et al. Am J Hum Genet. 2001 69: 969 [PMID: 11565064]

Edited by $P$ Kangueane

Citation: Nassa et al. Bioinformation 8(1): 026-033 (2012)

License statement: This is an open-access article, which permits unrestricted use, distribution, and reproduction in any medium, for non-commercial purposes, provided the original author and source are credited. 


\section{Supplementary materials:}

Table 1: Functional properties of human collagens in diseases:

\begin{tabular}{|c|c|c|c|c|}
\hline Collagen & $\begin{array}{l}\text { Accession } \\
\text { number }\end{array}$ & Collagen name & Function & Involvement in disease \\
\hline Col 1 & P02452 & $\begin{array}{l}\text { CO1A1_HUMAN } \\
\text { Collagen alpha-1(I) } \\
\text { chain }\end{array}$ & $\begin{array}{l}\text { Fibrillar forming collagen in bones } \\
\text { tendons ligaments }\end{array}$ & $\begin{array}{l}\text { Mutation results in } \\
\text { Dwarfism,Ehlers-Danlos } \\
\text { syndrome and } \\
\text { Osteogenesis imperfecta }\end{array}$ \\
\hline Col 2 & P02458 & $\begin{array}{l}\text { CO2A1_HUMAN } \\
\text { Collagen alpha-1(II) } \\
\text { chain }\end{array}$ & $\begin{array}{l}\text { Normal embryonic development of } \\
\text { skeleton,linear growth }\end{array}$ & $\begin{array}{l}\text { Cataract,deafness and muation } \\
\text { causes stickler syndrome and } \\
\text { dwarfism }\end{array}$ \\
\hline Col 3 & P02461 & $\begin{array}{l}\text { CO3A1_HUMAN } \\
\text { Collagen alpha-1(III) } \\
\text { chain }\end{array}$ & $\begin{array}{l}\text { Fibrillar forming collagen like type } 1 \\
\text { collagen,formation of connective tissue }\end{array}$ & $\begin{array}{l}\text { Muation causes Aortic aneurysm, } \\
\text { Ehlers-Danlos syndrome }\end{array}$ \\
\hline Col 4 & P02462 & $\begin{array}{l}\text { CO4A1_HUMAN } \\
\text { Collagen alpha-1(IV) } \\
\text { chain }\end{array}$ & $\begin{array}{l}\text { Formation of 'chicken wire' meshwork } \\
\text { in glomerulus tissue, thus involved in } \\
\text { filtering of urine in kidney }\end{array}$ & Alport syndrome \\
\hline Col 5 & P20908 & $\begin{array}{l}\text { CO5A1_HUMAN } \\
\text { Collagen alpha-1(V) } \\
\text { chain }\end{array}$ & $\begin{array}{l}\text { Fibrillar forming, binds to } \\
\text { dna,fibrin,heparin and insulin }\end{array}$ & Ehlers-Danlos syndrome \\
\hline Col 6 & P12109 & $\begin{array}{l}\text { CO6A1_HUMAN } \\
\text { Collagen alpha-1(VI) } \\
\text { chain }\end{array}$ & Cell binding protein & $\begin{array}{l}\text { Ulrich myopathy and Bethlem } \\
\text { myopathy }\end{array}$ \\
\hline Col 7 & Q02388 & $\begin{array}{l}\text { CO7A1_HUMAN } \\
\text { Collagen alpha-1(VII) } \\
\text { chain }\end{array}$ & $\begin{array}{l}\text { Basement membrane organization and } \\
\text { adherence }\end{array}$ & epidermolysis bullosa dystrophica \\
\hline Col 8 & P27658 & $\begin{array}{l}\text { CO8A1_HUMAN } \\
\text { Collagen alpha-1(VIII) } \\
\text { chain }\end{array}$ & $\begin{array}{l}\text { Proliferation of vscular smooth muscle } \\
\text { cells,maintains vessel wall integrity and } \\
\text { structure }\end{array}$ & $\begin{array}{l}\text { Posterior polymorphous corneal } \\
\text { dystrophy } 2\end{array}$ \\
\hline Col 9 & P20849 & $\begin{array}{l}\text { CO9A1_HUMAN } \\
\text { Collagen alpha-1(IX) } \\
\text { chain }\end{array}$ & $\begin{array}{l}\text { Flexible hence connects type II collagen } \\
\text { to other cartilage components }\end{array}$ & $\begin{array}{l}\text { Osteoarthritis,muatation may } \\
\text { result in epiphyseal dysplasia and } \\
\text { stickler syndrome }\end{array}$ \\
\hline Col 10 & Q03692 & $\begin{array}{l}\text { COAA1_HUMAN } \\
\text { Collagen alpha-1(X) } \\
\text { chain }\end{array}$ & - & $\begin{array}{l}\text { Schmid type metaphyseal } \\
\text { chondrodysplasia }\end{array}$ \\
\hline Col 11 & P12107 & $\begin{array}{l}\text { COBA1_HUMAN } \\
\text { Collagen alpha-1(XI) } \\
\text { chain }\end{array}$ & $\begin{array}{l}\text { Important role in fibrillogenesis by } \\
\text { controlling growth of collagen II fibrils }\end{array}$ & $\begin{array}{l}\text { Marshall syndrome and stickler } \\
\text { syndrome }\end{array}$ \\
\hline Col 12 & Q99715 & $\begin{array}{l}\text { COCA1_HUMAN } \\
\text { Collagen alpha-1(XII) } \\
\text { chain }\end{array}$ & $\begin{array}{l}\text { Modifies surrounding matrix by } \\
\text { interaction with type I collagen }\end{array}$ & N.D \\
\hline Col 13 & Q5TAT6 & $\begin{array}{l}\text { CODA1_HUMAN } \\
\text { Collagen alpha-1(XIII) } \\
\text { chain }\end{array}$ & $\begin{array}{l}\text { Cell-matrix and cell-cell interactions for } \\
\text { normal development }\end{array}$ & - \\
\hline Col 14 & Q05707 & $\begin{array}{l}\text { COEA1_HUMAN } \\
\text { Collagen alpha-1(XIV) } \\
\text { chain }\end{array}$ & $\begin{array}{l}\text { Interacts with collagen } \\
\text { bundles, adhesion }\end{array}$ & - \\
\hline Col 15 & P39059 & $\begin{array}{l}\text { COFA1_HUMAN } \\
\text { Collagen alpha-1(XV) } \\
\text { chain }\end{array}$ & $\begin{array}{l}\text { Stabilizes microvessels and muscle cells } \\
\text { in heart and skeletal muscle,inhibits } \\
\text { angiogenesis }\end{array}$ & - \\
\hline Col 16 & Q07092 & $\begin{array}{l}\text { COGA1_HUMAN } \\
\text { Collagen alpha-1(XVI) } \\
\text { chain }\end{array}$ & $\begin{array}{l}\text { Induces integrin mediated } \\
\text { interactions:Cell spreading, attachment } \\
\text { and alteration of morphlogy of cells }\end{array}$ & - \\
\hline Col 17 & Q9UMD9 & $\begin{array}{l}\text { COHA1_HUMAN } \\
\text { Collagen alpha-1(XVII) }\end{array}$ & $\begin{array}{l}\text { Role in maintaining integrity of } \\
\text { hemidesmosome, attachment of basal } \\
\text { keratinocytes basement membrane. }\end{array}$ & - \\
\hline Col 18 & P39060 & $\begin{array}{l}\text { COIA1_HUMAN } \\
\text { Collagen alpha-1(XVIII) } \\
\text { chain }\end{array}$ & $\begin{array}{l}\text { Determination of renal structure and } \\
\text { closure of renal tube,inhibits } \\
\text { angiogenesis }\end{array}$ & - \\
\hline
\end{tabular}




\begin{tabular}{|c|c|c|c|}
\hline Col 19 & Q14993 & $\begin{array}{l}\text { COJA1_HUMAN } \\
\text { Collagen alpha-1(XIX) } \\
\text { chain }\end{array}$ & $\begin{array}{l}\text { Esophagus development,organization } \\
\text { of pericellular matrix }\end{array}$ \\
\hline Col 20 & Q9P218 & $\begin{array}{l}\text { COKA1_HUMAN } \\
\text { Collagen alpha- } 1(X X) \\
\text { chain }\end{array}$ & - \\
\hline Col 21 & Q96P44 & $\begin{array}{l}\text { COLA1_HUMAN } \\
\text { Collagen alpha-1(XXI) } \\
\text { chain }\end{array}$ & - \\
\hline Col 22 & Q8NFW1 & $\begin{array}{l}\text { COMA1_HUMAN } \\
\text { Collagen alpha-1(XXII) } \\
\text { chain }\end{array}$ & $\begin{array}{l}\text { Acts as a cell adhesion ligand for skin } \\
\text { epithelial cells and fibroblasts }\end{array}$ \\
\hline Col 23 & Q86Y22 & $\begin{array}{l}\text { CONA1_HUMAN } \\
\text { Collagen alpha-1(XXIII) } \\
\text { chain }\end{array}$ & - \\
\hline Col 24 & Q17RW2 & $\begin{array}{l}\text { COOA1_HUMAN } \\
\text { Collagen alpha-1(XXIV) } \\
\text { chain }\end{array}$ & $\begin{array}{l}\text { Regulation of type I collagen } \\
\text { fibrillogenesis at specific anatomical } \\
\text { locations during fetal development }\end{array}$ \\
\hline Col 25 & Q9BXS0 & $\begin{array}{l}\text { COPA1_HUMAN } \\
\text { Collagen alpha-1(XXV) } \\
\text { chain }\end{array}$ & $\begin{array}{l}\text { Binds heparin, assembles amyloid fibrils } \\
\text { into protease resisitant aggregates }\end{array}$ \\
\hline Col 26 & Q96A83 & $\begin{array}{l}\text { EMID2_HUMAN } \\
\text { Collagen alpha-1(XXVI) } \\
\text { chain }\end{array}$ & - \\
\hline Col 27 & Q8IZC6 & $\begin{array}{l}\text { CORA1_HUMAN } \\
\text { Collagen alpha- } \\
1(\text { XXVII) chain }\end{array}$ & $\begin{array}{l}\text { calcification of cartilage and the } \\
\text { transition of cartilage to bone }\end{array}$ \\
\hline Col 28 & Q2UY09 & $\begin{array}{l}\text { COSA1_HUMAN } \\
\text { Collagen alpha- } \\
1 \text { (XXVIII) chain }\end{array}$ & May act as a cell binding protein \\
\hline
\end{tabular}

*N.D. - Not defined

Table 2: Amino acid composition of human alpha-1 collagens (in \%) :

\begin{tabular}{|c|c|c|c|c|c|c|c|c|c|c|c|c|c|c|c|c|c|c|c|c|}
\hline Collagen & Ala & Arg & Asn & Asp & Cys & Gln & Glu & Gly & His & Ile & Leu & Lys & Met & Phe & Pro & Ser & Thr & Trp & Tyr & Val \\
\hline Col 1 & 9.5 & 4.8 & 1.2 & 4.5 & 1.2 & 3.3 & 5.1 & 26.7 & 0.6 & 1.6 & 3.3 & 3.9 & 0.9 & 1.8 & 19 & 4.1 & 3.1 & 0.4 & 0.9 & 3.2 \\
\hline Col 2 & 9 & 4.8 & 2.2 & 4.2 & 1.3 & 4 & 5.3 & 27.3 & 0.5 & 2.3 & 3.8 & 4.5 & 1.1 & 1.7 & 18.2 & 3.2 & 3.0 & 0.5 & 0.7 & 2.6 \\
\hline Col 3 & 7.8 & 4.1 & 2.8 & 3.8 & 1.5 & 2.9 & 5.0 & 28.2 & 1.0 & 2.5 & 3.3 & 4.2 & 1.2 & 1.6 & 19.2 & 5.0 & 2.1 & 0.5 & 0.1 & 2.5 \\
\hline Col 4 & 3.5 & 2.7 & 1.0 & 3.5 & 1.2 & 4.4 & 4.2 & 28.6 & 1.0 & 3.5 & 5.5 & 5.6 & 1.9 & 2.8 & 19.4 & 4.3 & 2.6 & 0.4 & 1.1 & 3.1 \\
\hline Col 5 & 5 & 3.8 & 1.8 & 5.7 & 0.7 & 4.0 & 6.5 & 23.3 & 0.9 & 2.8 & 5.3 & 5.3 & 1.3 & 2.1 & 18.2 & 3.8 & 3.8 & 0.4 & 2.2 & 2.9 \\
\hline Col 6 & 7.5 & 5.8 & 2.7 & 6.9 & 1.9 & 4.1 & 6.6 & 15.2 & 1.4 & 4.1 & 6.9 & 5.3 & 1.1 & 3.2 & 8.7 & 5.3 & 4 & 0.4 & 2.7 & 6.3 \\
\hline Col 7 & 6.6 & 7.4 & 0.9 & 4.9 & 0.6 & 3.6 & 6.4 & 21.3 & 1.0 & 1.9 & 7.2 & 3.2 & 0.6 & 1.3 & 14.5 & 5.6 & 4.5 & 0.6 & 1.2 & 6.8 \\
\hline Col 8 & 4.4 & 1.7 & 1.1 & 1.5 & 0.3 & 5.1 & 3.5 & 25.9 & 1.5 & 4.4 & 7.1 & 6.3 & 3.1 & 2.3 & 22.4 & 1.5 & 1.1 & 0.1 & 3.0 & 4.0 \\
\hline Col 9 & 5.1 & 5.9 & 2.2 & 4.2 & 1.2 & 4.2 & 5.1 & 23.6 & 0.9 & 3.9 & 6.2 & 4.6 & 1.3 & 2.4 & 16.6 & 4.6 & 2.8 & 0.7 & 0.7 & 4.0 \\
\hline Col 10 & 5.3 & 2.8 & 2.1 & 1.8 & 0.1 & 3.4 & 3.2 & 25.7 & 1.5 & 4 & 5.1 & 5.1 & 1.6 & 2.2 & 21.3 & 4 & 3.5 & 0.3 & 3.1 & 3.8 \\
\hline Col 11 & 5.4 & 3.8 & 2.0 & 5.5 & 0.6 & 4.5 & 6.8 & 23.4 & 0.9 & 3.1 & 4.4 & 5.9 & 1.3 & 2. & 15.9 & 4 & 3.8 & 0.5 & 2.0 & 3.5 \\
\hline Col 12 & 5.2 & 5.1 & 3.9 & 5.6 & 0.7 & 3.4 & 6.3 & 9.2 & 1.0 & 4.8 & 6.6 & 5.1 & 1.5 & 3.0 & 8.6 & 7.9 & 8.7 & 1.0 & 3.7 & 8.8 \\
\hline Col 13 & 6.8 & 4.9 & 1.5 & 3.2 & 1.1 & 3.9 & 6.1 & 25.7 & 1.5 & 2.6 & 7.4 & 6.4 & 1.8 & 0.7 & 17.4 & 3.3 & 2.4 & 0.3 & 0.4 & 2.4 \\
\hline Col 14 & 5.2 & 4.1 & 3.2 & 5.2 & 1.1 & 4.0 & 6.6 & 10.9 & 1.6 & 5.5 & 7.2 & 4.8 & 1.8 & 3.3 & 8.7 & 7.4 & 7.6 & 1.0 & 3.0 & 7.9 \\
\hline Col 15 & 7.8 & 3.4 & 2.7 & 4.2 & 0.7 & 2.9 & 7.0 & 15.9 & 1.8 & 3.9 & 8.1 & 3.7 & 2.2 & 3.1 & 13.8 & 7.1 & 5.3 & 0.7 & 1.0 & 4.7 \\
\hline Col 16 & 5.3 & 3.9 & 1.4 & 3.2 & 2 & 4.9 & 5.7 & 24.4 & 1.2 & 2.6 & 7.1 & 5.4 & 1.6 & 1.9 & 17.6 & 4.7 & 2.7 & 0.5 & 0.8 & 3.9 \\
\hline Col 17 & 5.7 & 4.5 & 2.1 & 3.6 & 0.5 & 3.2 & 4.2 & 18.8 & 1.5 & 2.7 & 8.4 & 4 & 2.2 & 1.7 & 13.6 & 11.9 & 5.6 & 0.7 & 2.4 & 3.9 \\
\hline Col 18 & 8 & 5.2 & 1.5 & 4.2 & 1.3 & 3.8 & 5.1 & 17.2 & 2.1 & 1.7 & 6.2 & 2.4 & 0.9 & 3.2 & 16.9 & 6.9 & 3.9 & 1.2 & 1.1 & 5.0 \\
\hline Col 19 & 4.6 & 4.1 & 2.6 & 4.3 & 1.2 & 4 & 5.9 & 22.9 & 1.4 & 5 & 10.7 & 6.7 & 1.6 & 2.2 & 15.1 & 4.6 & 2.6 & 0.6 & 1.4 & 2.9 \\
\hline Col 20 & 8.9 & 6.6 & 0.9 & 3.6 & 1 & 4.4 & 5.7 & 11.5 & 2.2 & 1.8 & 6.9 & 3 & 1.1 & 2.7 & 10 & 8. & 6.7 & 1.3 & 2.0 & 7.6 \\
\hline Col 21 & 4.2 & 4 & 2.7 & 5 & 1.5 & 5.3 & 5.2 & 18.9 & 1.1 & 5.6 & 6.2 & 7.1 & 1.3 & 3.0 & 11.1 & 5.2 & 3.6 & 0.4 & 2.3 & 5.5 \\
\hline Col 22 & 5.8 & 5.2 & 1.5 & 4.3 & 1.1 & 3.8 & 6.4 & 24.4 & 1.2 & 2.8 & 7.4 & 5.4 & 1.2 & 2.1 & 16.4 & 4.1 & 2.6 & 0.4 & 1.0 & 4.3 \\
\hline Col 23 & 8 & 3.9 & 0.4 & 5.4 & 1.1 & 3.1 & 6.7 & 27.2 & 0.6 & 1.5 & 7.5 & 6.5 & 0.9 & 0.4 & 17.2 & 3.1 & 1.5 & 0.4 & 0.4 & 2.8 \\
\hline Col 24 & 3.4 & 4.3 & 3.3 & 3.5 & 0.9 & 5.3 & 6 & 21.3 & 2.2 & 5.1 & 6.3 & 6.1 & 1.4 & 2.5 & 12.1 & 5.3 & 4.6 & 0.3 & 1.8 & 4.0 \\
\hline Col 25 & 5 & 6.3 & 1.4 & 4.3 & 1.1 & 4.9 & 6.9 & 25.5 & 1.5 & 3.1 & 8.8 & 7.6 & 2.6 & 0.8 & 16.5 & 3.1 & 2.4 & 0.2 & 0.6 & 2.0 \\
\hline Col 26 & 8.6 & 5.4 & 2.3 & 3.6 & 2.9 & 4.1 & 5.4 & 14.7 & 1.6 & 1.6 & 7.2 & 2.7 & 1.4 & 0.9 & 15.4 & 6.6 & 5.2 & 1.1 & 1.8 & 4.8 \\
\hline Col 27 & 5.9 & 3.6 & 1.1 & 3.7 & 0.8 & 5.2 & 3.6 & 21.3 & 1.7 & 2.4 & 5.9 & 5.1 & 2 & 2.6 & 16.3 & 5.7 & 4.7 & 0.5 & 0.9 & 3.8 \\
\hline Col 28 & 3.7 & 3.6 & 2.4 & 5.6 & 1.3 & 5.2 & 6.5 & 18.8 & 0.6 & 5.4 & 5.9 & 8.1 & 1.2 & 3.4 & 11.5 & 6.1 & 4 & 0.4 & 1.6 & 4.7 \\
\hline
\end{tabular}

${ }^{*}$ Col- Collagens 
Table 3(a): Physico-chemical parameters of human alpha-1 collagens:

\begin{tabular}{|c|c|c|c|c|c|c|c|c|c|}
\hline Collagen & $\begin{array}{l}\text { No. of } \\
\text { amino acids }\end{array}$ & $\begin{array}{l}\text { Molecular } \\
\text { weight }\end{array}$ & pI & $\begin{array}{l}\text { '-' charged } \\
\text { residue }\end{array}$ & $\begin{array}{l}\text { ' }+ \text { charged } \\
\text { residue }\end{array}$ & $\begin{array}{l}\text { Extinction } \\
\text { Coefficient }\end{array}$ & $\begin{array}{l}\text { Instability } \\
\text { index }\end{array}$ & $\begin{array}{l}\text { Aliphatic } \\
\text { index }\end{array}$ & GRAVY \\
\hline Col 1 & 1464 & 138941.5 & 5.6 & 141 & 128 & 53495 & 30.43 & 37.98 & -0.788 \\
\hline Col 2 & 1487 & 141785.3 & 6.58 & 141 & 139 & 54525 & 25.21 & 40.03 & -0.803 \\
\hline Col 3 & 1466 & 138564.2 & 6.21 & 129 & 122 & 62225 & 30.18 & 37.31 & -0.797 \\
\hline Col 4 & 1669 & 1606147.7 & 8.55 & 128 & 138 & 61070 & 32.04 & 47.39 & -0.621 \\
\hline Col 5 & 1838 & 183559.8 & 4.94 & 225 & 168 & 98850 & 33.09 & 45.35 & -0.873 \\
\hline Col 6 & 1028 & 108529.4 & 5.26 & 139 & 114 & 64970 & 28.52 & 68.7 & -0.525 \\
\hline Col 7 & 2944 & 295219.6 & 5.95 & 332 & 310 & 159140 & 32.07 & 61.86 & -0.625 \\
\hline Col 8 & 744 & 73364 & 9.62 & 37 & 60 & 38405 & 36.06 & 61.21 & -0.434 \\
\hline Col 9 & 921 & 91869.2 & 8.94 & 86 & 96 & 42565 & 32.61 & 56.13 & -0.658 \\
\hline Col 10 & 680 & 66157.9 & 9.68 & 34 & 54 & 42290 & 25.95 & 51.94 & -0.556 \\
\hline Col 11 & 1806 & 181064.8 & 5.06 & 222 & 174 & 103765 & 30.81 & 44.91 & -0.859 \\
\hline Col 12 & 3063 & 333146.7 & 5.38 & 366 & 313 & 334620 & 32.90 & 75.45 & -0.427 \\
\hline Col 13 & 717 & 69949.9 & 9.27 & 67 & 81 & 15970 & 31.44 & 52.87 & -0.765 \\
\hline Col 14 & 1796 & 193515.4 & 5.16 & 211 & 160 & 179095 & 37.57 & 77.67 & -0.326 \\
\hline Col 15 & 1388 & 141720.1 & 4.9 & 155 & 95 & 76485 & 40.19 & 68 & -0.377 \\
\hline Col 16 & 1604 & 157751.3 & 8.14 & 144 & 150 & 65370 & 35.88 & 50.73 & -0.671 \\
\hline Col 17 & 1497 & 150419.3 & 8.89 & 117 & 128 & 109015 & 45.25 & 55.47 & -0.573 \\
\hline Col 18 & 1754 & 178187.6 & 5.67 & 164 & 133 & 145185 & 48.57 & 61.72 & -0.467 \\
\hline Col 19 & 1142 & 115220.7 & 8.57 & 116 & 124 & 63215 & 30.68 & 56.68 & -0.708 \\
\hline Col 20 & 1284 & 135830 & 8.27 & 119 & 123 & 132990 & 45.18 & 79.61 & -0.261 \\
\hline Col 21 & 957 & 99368.5 & 8.57 & 98 & 106 & 55655 & 33.28 & 69.14 & -0.517 \\
\hline Col 22 & 1626 & 161145.3 & 6.88 & 174 & 172 & 57965 & 34 & 53.28 & -0.715 \\
\hline Col 23 & 540 & 51943.9 & 6.88 & 65 & 65 & 14355 & 30.81 & 50.69 & -0.829 \\
\hline Col 24 & 1714 & 175496.3 & 8.46 & 162 & 170 & 73075 & 28.32 & 64.21 & -0.622 \\
\hline Col 25 & 654 & 64770.7 & 8.6 & 73 & 78 & 11835 & 24.85 & 47.19 & -0.919 \\
\hline Col 26 & 441 & 45381.1 & 7.02 & 40 & 40 & 40170 & 46.77 & 63.11 & -0.523 \\
\hline Col 27 & 1860 & 186892.3 & 9.83 & 136 & 196 & 81205 & 37.62 & 54.15 & -0.637 \\
\hline Col 28 & 1125 & 116657.1 & 6.1 & 136 & 131 & 55195 & 24.18 & 61.42 & -0.66 \\
\hline
\end{tabular}

${ }^{*}$ Col- Collagens

Table 3(b): Physico-chemical properties of human alpha-1 collagens

\begin{tabular}{|c|c|c|c|c|c|c|c|c|c|c|c|}
\hline Collagen & $\begin{array}{l}\text { No. of } \\
\text { codons }\end{array}$ & $\begin{array}{l}\text { Bulki- } \\
\text { ness }\end{array}$ & Polarity & Refractivity & $\begin{array}{l}\text { Recognit } \\
\text { ion } \\
\text { factors }\end{array}$ & $\begin{array}{l}\text { Hydro- } \\
\text { phobicity }\end{array}$ & $\begin{array}{l}\text { Trans- } \\
\text { membrane } \\
\text { tendency }\end{array}$ & $\begin{array}{l}\% \\
\text { buried } \\
\text { residues }\end{array}$ & $\begin{array}{l}0 \% \\
\text { accessible } \\
\text { residues }\end{array}$ & $\begin{array}{l}\text { Average } \\
\text { area } \\
\text { buried }\end{array}$ & $\begin{array}{l}\text { Average } \\
\text { flexibility }\end{array}$ \\
\hline Col1 & 3.889 & 14.3645 & 17.2635 & 14.4125 & 87.5 & -0.2835 & -0.6295 & 6.528 & 5.622 & 118.5835 & 0.4505 \\
\hline Col2 & 3.611 & 14.535 & 17.012 & 14.417 & 89.722 & 0.05 & -0.434 & 6.9445 & 5.9665 & 116.9055 & 0.452 \\
\hline Col3 & 3.889 & 13.688 & 14.3925 & 14.1385 & 88.889 & -0.222 & -0.3985 & 7.3885 & 5.65 & 116.239 & 0.4505 \\
\hline Col4 & 3.722 & 13.466 & 16.9645 & 14.739 & 89.6115 & 0.0115 & -0.564 & 6.561 & 5.9555 & 120.7055 & 0.4445 \\
\hline Col5 & 3.889 & 13.905 & 16.8185 & 15.437 & 88.5555 & -0.089 & -0.429 & 6.1335 & 5.9 & 117.989 & 0.452 \\
\hline Col6 & 3.5555 & 13.866 & 17.659 & 16.544 & 88.7225 & -0.0225 & -0.5395 & 5.95 & 5.672 & 116.35 & 0.453 \\
\hline Col7 & 3.7775 & 14.1405 & 17.502 & 14.787 & 90.611 & -0.139 & -0.6305 & 6.767 & 5.9445 & 118.028 & 0.4485 \\
\hline Col8 & 3.722 & 13.8405 & 14.092 & 15.435 & 88.389 & -0.1835 & -0.3875 & 6.5835 & 5.8725 & 119.7725 & 0.4455 \\
\hline Col9 & 3.5555 & 14.563 & 17.537 & 16.071 & 87.5555 & -0.0055 & -0.3405 & 6 & 5.422 & 122.5835 & 0.444 \\
\hline Col10 & 3.722 & 14.577 & 12.346 & 14.2365 & 88.5555 & -0.2665 & -0.3025 & 6.25 & 5.661 & 119.7725 & 0.4555 \\
\hline Col11 & 3.4445 & 13.735 & 17.296 & 16.398 & 89 & -0.55 & -0.6195 & 6.611 & 6.0665 & 122.972 & 0.45 \\
\hline Col12 & 3.722 & 14.226 & 16.8455 & 15.1145 & 90 & -0.078 & -0.5105 & 6.9225 & 5.9335 & 121.2225 & 0.454 \\
\hline Col13 & 3.833 & 13.779 & 20.1465 & 15.135 & 80.0555 & -0.2335 & -0.55 & 6.4615 & 5.9835 & 118.511 & 0.4495 \\
\hline Col14 & 3.5555 & 14.611 & 19.96 & 15.7995 & 89.3335 & -0.283 & -0.843 & 5.622 & 5.7055 & 122.35 & 0.4495 \\
\hline Col15 & 3.72205 & 13.5155 & 16.584 & 15.1545 & 87.444 & -0.033 & -0.513 & 6.861 & 5.4945 & 119.6555 & 0.443 \\
\hline Col16 & 3.5 & 14.316 & 17.226 & 15.108 & 88.2775 & 0.1775 & -0.357 & 6.1055 & 5.789 & 120.672 & 0.448 \\
\hline Col17 & 3.889 & 12.439 & 17.232 & 15.038 & 92.333 & -0.1165 & -0.3895 & 7.1615 & 6.122 & 116.522 & 0.454 \\
\hline Col18 & 3.889 & 13.5065 & 17.062 & 14.587 & 89.444 & 0.3335 & -0.3765 & 6.3385 & 5.5275 & 122.828 & 0.4335 \\
\hline Col19 & 3.5 & 14.179 & 17.4405 & 16.2065 & 87.4445 & -0.622 & -0.4485 & 6.311 & 5.7165 & 126.9225 & 0.4445 \\
\hline Col20 & 3.7775 & 14.161 & 19.7095 & 15.07 & 90.6665 & -0.3335 & -0.5825 & 6.828 & 5.9115 & 124.783 & 0.4425 \\
\hline Col21 & 3.5555 & 14.8025 & 16.9925 & 15.4085 & 88.0555 & -0.3335 & -0.3235 & 6.256 & 5.811 & 123.1165 & 0.439 \\
\hline Col22 & 3.722 & 14.055 & 17.253 & 15.4765 & 87.056 & 0.222 & -0.32 & 6.4555 & 5.911 & 124.278 & 0.4435 \\
\hline Col23 & 3.9445 & 11.8145 & 19.881 & 11.6245 & 87.222 & -0.017 & -0.5535 & 5.63385 & 6 & 109.889 & 0.4535 \\
\hline Col24 & 3.722 & 14.5095 & 17.514 & 15.4565 & 89.1115 & -0.2555 & -0.472 & 7.1 & 5.8225 & 119.835 & 0.4395 \\
\hline Col25 & 3.7225 & 13.5035 & 17.207 & 13.0145 & 87.3885 & 0.011 & -0.534 & 7.289 & 5.6555 & 113.683 & 0.4545 \\
\hline Col26 & 3.167 & 13.7255 & 14.878 & 15.4075 & 87.8885 & -0.3055 & -0.593 & 6.767 & 5.2225 & 116.1885 & 0.4455 \\
\hline Col27 & 3.611 & 13.9525 & 17.331 & 14.9185 & 90.889 & -0.111 & -0.3675 & 6.55 & 6.011 & 119.067 & 0.445 \\
\hline Col28 & 3.5555 & 14.7145 & 19.934 & 16.194 & 88.3335 & -0.183 & -0.5865 & 6.022 & 5.7165 & 127.9725 & 0.446 \\
\hline
\end{tabular}

*Col- Collagens 
Table 4: Secondary structural features of human alpha-1 collagens (in \%):

\begin{tabular}{|c|c|c|c|c|c|c|c|c|c|c|}
\hline Collagen & $\begin{array}{l}\text { a } \\
\text { helix }\end{array}$ & $\begin{array}{l}3_{10} \\
\text { helix }\end{array}$ & $\begin{array}{l}\text { Pi } \\
\text { helix }\end{array}$ & $\begin{array}{l}\beta \\
\text { bridge }\end{array}$ & $\begin{array}{l}\text { Extended } \\
\text { strand }\end{array}$ & $\begin{array}{l}\beta \\
\text { turn }\end{array}$ & $\begin{array}{l}\text { Bend } \\
\text { region }\end{array}$ & $\begin{array}{l}\text { Random } \\
\text { coil }\end{array}$ & $\begin{array}{l}\text { Ambiguous } \\
\text { states }\end{array}$ & $\begin{array}{l}\text { Other } \\
\text { states }\end{array}$ \\
\hline Col1 & 4.37 & 0 & 0 & 0 & 8.13 & 4.3 & 0 & 83.2 & 0 & 0 \\
\hline Col2 & 6.27 & 0 & 0 & 0 & 7.2 & 4.57 & 0 & 81.51 & 0 & 0 \\
\hline Col4 & 4.73 & 0 & 0 & 0 & 7.61 & 5.69 & 0 & 81.97 & 0 & 0 \\
\hline Col5 & 7.94 & 0 & 0 & 0 & 11.53 & 4.9 & 0 & 75.63 & 0 & 0 \\
\hline Col8 & 5.65 & 0 & 0 & 0 & 10.89 & 9.41 & 0 & 74.06 & 0 & 0 \\
\hline Col9 & 9.45 & 0 & 0 & 0 & 7.17 & 3.37 & 0 & 80.02 & 0 & 0 \\
\hline Col10 & 3.97 & 0 & 0 & 0 & 12.35 & 5 & 0 & 78.68 & 0 & 0 \\
\hline Col11 & 8.36 & 0 & 0 & 0 & 12.02 & 5.59 & 0 & 74.03 & 0 & 0 \\
\hline Col12 & 13.12 & 0 & 0 & 0 & 25.56 & 4.9 & 0 & 56.42 & 0 & 0 \\
\hline Col17 & 19.91 & 0 & 0 & 0 & 11.89 & 6.95 & 0 & 61.26 & 0 & 0 \\
\hline Col18 & 17.56 & 0 & 0 & 0 & 12.43 & 6.9 & 0 & 63.11 & 0 & 0 \\
\hline Col19 & 13.57 & 0 & 0 & 0 & 9.54 & 6.04 & 0 & 70.84 & 0 & 0 \\
\hline Col20 & 18.15 & 0 & 0 & 0 & 21.65 & 5.69 & 0 & 54.52 & 0 & 0 \\
\hline Col21 & 15.26 & 0 & 0 & 0 & 12.43 & 4.7 & 0 & 67.61 & 0 & 0 \\
\hline Col22 & 11.38 & 0 & 0 & 0 & 10.7 & 7.56 & 0 & 70.36 & 0 & 0 \\
\hline Col23 & 13.7 & 0 & 0 & 0 & 0.56 & 1.3 & 0 & 84.44 & 0 & 0 \\
\hline Col24 & 7.41 & 0 & 0 & 0 & 9.33 & 2.92 & 0 & 80.34 & 0 & 0 \\
\hline Col25 & 12.69 & 0 & 0 & 0 & 4.43 & 3.82 & 0 & 79.05 & 0 & 0 \\
\hline Col26 & 24.94 & 0 & 0 & 0 & 11.11 & 5.9 & 0 & 58.05 & 0 & 0 \\
\hline Col27 & 9.46 & 0 & 0 & 0 & 11.88 & 5.86 & 0 & 72.8 & 0 & 0 \\
\hline
\end{tabular}

*Col- Collagen

Table 5: Motifs in human alpha-1 collagens:

\begin{tabular}{|c|c|c|c|c|c|c|c|c|}
\hline Collagen & Motif found & $\begin{array}{l}\text { Motif } \\
\text { ID }\end{array}$ & Description & & & Start & End & Match Status Significance \\
\hline Col1 & VWFC_1 & PS01208 & VWFC domain signature & & & 58 & 95 & Strong match; not a false positive \\
\hline Col2 & VWFC_1 & PS01208 & VWFC domain signature & & & 52 & 89 & Strong match; not a false positive \\
\hline Col3 & VWFC_1 & PS01208 & VWFC domain signature & & & 50 & 88 & Strong match; not a false positive \\
\hline Col7 & BPTI_KUNITZ_1 & PS00280 & $\begin{array}{l}\text { Pancreatic trypsin inhibitor } \\
\text { signature }\end{array}$ & (Kunitz) & family & 2907 & 2925 & Strong match; not a false positive \\
\hline Col28 & BPTI_KUNITZ_1 & PS00280 & $\begin{array}{l}\text { Pancreatic trypsin inhibitor } \\
\text { signature }\end{array}$ & (Kunitz) & family & 1100 & 1118 & Strong match; not a false positive \\
\hline
\end{tabular}

*VWFC: von Willebrand factor (VWF) type C repeat

${ }^{* *}$ No motifs were found in remaining human alpha-1 collagen sequences

*** Col- Collagen 